\title{
Pengaruh Model Pembelajaran Kooperatif Two Stay Two Stray Berbantuan Mind Mapping terhadap Hasil Belajar IPA
}

\author{
*I Gusti Ayu Sri Juniantari ${ }^{1}$, Ni Nyoman Kusmariyatni² \\ 1,2 Jurusan Pendidikan Guru Sekolah Dasar, Fakultas Ilmu Pendidikan, Universitas Pendidikan Ganesha, Singaraja, Indonesia
}

\section{A R T I C L E I N F O}

Article history:

Received 10 May 2019

Received in revised form 10 June 2019

Accepted 15 July 2019 Available online 29 August 2019

Kata Kunci:
mind mapping, two stay two
stray

Keywords:

mind mapping, two stay two stray

kooperatif Two Stay Two Stray berbantuan Mind Mapping dan kelompok siswa yang dibelajarkan kooperatif Two Stay Two Stray berbantuan Mind Mapping dan kelompok siswa yang dibelajarkan
dengan pembelajaran konvensional. Berdasarkan hasil penelitian tersebut dapat disimpulkan bahwa model pembelajaran kooperatif Two Stay Two Stray berbantuan Mind Mapping berpengaruh terhadap hasil belajar IPA.

\begin{abstract}
A B S T R A K
Berdasarkan hasil observasi, dimana hasil belajar IPA siswa masih rendah. Penelitian ini bertujuan untuk mengetahui perbedaan yang signifikan hasil belajar IPA antara kelompok siswa yang dibelajarkan dengan model pembelajaran kooperatif Two Stay Two Stray berbantuan Mind Mapping dan kelompok siswa yang dibelajarkan dengan pembelajaran konvensional pada siswa kelas V SD. Penelitian ini merupakan penelitian kuasi eksperimen dengan rancangan nonequivalent post-test only control group design. Populasi penelitian ini adalah siswa kelas V SD yang berjumlah 75 orang. Pengambilan sampel dilakukan dengan menggunakan teknik random sampling yang terdiri dari kelas eksperimen dan kelas kontrol. Metode pengumpulan data menggunakan instrumen tes hasil belajar IPA. Data yang diperoleh dianalisis dalam dua tahap yaitu, dengan analisis statistik deskriptif dan analisis statistik inferensial melalui uji-t. Hasil penelitian menunjukkan bahwa terdapat perbedaan yang signifikan hasil belajar IPA antara kelompok siswa yang dibelajarkan dengan model pembelajaran
\end{abstract} A B S T R A C T

\begin{abstract}
This study aimed to find out the significant differences in science learning between groups of students who were studied with a cooperative learning model Two Stay Two Stray assisting by Mind Mapping and the students who were learning with a conventional learning at fifth garde of elemetary school on 2017/2018. This research was a quasi-experimental research using the non-equivalent post-test only control group design. The population of this research was 75 fifth grade students at Gugus VIII Sukasada district on 2017/2018. Sampling was done by random sampling technique. The sample of this research was fifth grade students at SD Negeri 4 as experiment class and fifth grade students at SD Negeri 2 as a control class. The data collected by using the learning science test instrument. The data analyzed by a descriptive statistic and an inferential statistics through $t$-test. It means that there was a significant difference in science learning among the students who learning with the cooperative learning model Two Stay Two Stray assisting by Mind Mapping and the students who learning with a conventional learning. Based on the results of the experiments it can be concluded that the cooperative learning model Two Stay Two Stray assisting by Mind Mapping gave effect to the science learning outcomes.
\end{abstract}

\section{Pendahuluan}

Proses pembelajaran merupakan suatu proses kegiatan yang di dalamnya terdapat interaksi antara guru dan siswa untuk mencapai tujuan belajar. Guru dan siswa dalam proses pembelajaran merupakan dua komponen yang tidak dapat dipisahkan. Dalam proses pembelajaran "kesiapan seorang

Copyright (®) Universitas Pendidikan Ganesha. All rights reserved. 
guru untuk mengenal karakteristik siswa dalam pembelajaran merupakan modal utama penyampaian bahan belajar dan menjadi indikator suksesnya pelaksanaan pembelajaran" Sagala (2012:62). Oleh karena itu, suksesnya pelaksanaan pembelajaran dipengaruhi oleh kemampuan guru dalam memahami karakteristik siswanya. Interaksi guru dan siswa dalam proses pembelajaran harus terjalin dengan baik agar hasil belajar siswa dapat tercapai secara optimal. Menurut Sagala (2012:62), "dari proses pembelajaran tersebut siswa memperoleh hasil belajar yang merupakan hasil dari suatu interaksi tindak belajar yaitu mengalami proses untuk meningkatkan kemampuan mentalnya dan tindak belajar yaitu membelajarkan siswa". Hasil belajar yang baik juga dapat dipengaruhi oleh lingkungan belajar siswa terutama dalam meningkatkan penalaran siswa terhadap pembelajaran yang diberikan oleh gurunya. Hasil belajar ini merupakan perubahan tingkah laku yang menyangkut bidang kognitif, afektif, dan psikomotor. Hal ini sejalan dengan pendapat Susanto(2013:5),makna hasil belajar yaitu "perubahanperubahan yang terjadi pada diri siswa, baik yang menyangkut aspek kognitif, afektif dan psikomotor sebagai hasil dari kegiatan belajar". Hasil belajar siswa yang tinggi akan menunjukkan tingkat kemampuan siswa dalam memahami materi.

Menurut Herawati (2015) belajar itu senantiasa merupakan perubahan tingkah laku atau penampilan, dengan serangkaian kegiatan misalnya dengan membaca, mengamati, mendengarkan, meniru dan lain sebagainya.Juga belajar itu akan lebih baik kalau subyek belajar itu mengalami atau melakukannya, jadi tidak bersifat verbalistik. Belajar sebagai kegiatan individu sebenarnya merupakan rangsangan-rangsangan individu yang dikirim kepadanya oleh lingkungan. Dengan demikian terjadinya kegiatan belajar yang dilakukan oleh seorang individu dapat dijelaskan dengan rumus antara individu dan lingkungan. Belajar menurut pandangan kontruktivisme adalah suatu proses pembelajaran yang mengkondisikan siswa untuk melakukan proses aktif membangun konsep baru, pengertian baru, dan pengetahuan baru berdasarkan data. Pandangan kontruktivisme mengubah orientasi pembelajaran dari pembelajaran yang berpusat pada guru menjadi pembelajaran yang berpusat pada siswa (Suwatra, 2015). Oleh karena itu, proses pembelajaran harus dirancang dan dikelola sedemikian rupa sehingga mampu mendorong siswa mengorganisasi pengalamannya sendiri menjadi pengetahuan yang bermakna. Peran guru dan siswa dalam proses pembelajaran sangatlah penting. Siswa berperan sebagai subyek pelaksana kegiatan pembelajaran dan guru berperan sebagai pengembang kurikulum dalam merancang proses pembelajaran. Siswa sebagai subyek pelaksana memiliki kemampuan kognitif yang berbeda-beda, sebagian siswa belajar secara mandiri dengan mendengar, membaca, melihat, namun sebagian perlu berinteraksi dengan lingkungan belajar seperti teman-temannya, guru, lingkungan kelas, sekolah bahkan perlu bekerja bersama dalam suatu kelompok kerja. Oleh karena itu, guru perlu menyediakan wahana, media, dan pendekatan cara belajar yang bervariasi dalam proses pembelajaran. Proses pembelajaran yang baik adalah dimana siswa memperoleh kesempatan untuk membangun sendiri pengetahuannya sehingga mereka akan memperoleh pemahaman yang mendalam dan pada akhirnya dapat meningkatkan mutu kualitas siswa. Tugas guru adalah sebagai fasilitator yang mendukung keaktifan siswa untuk membangun pengetahuannya secara mandiri. Untuk menciptakan suatu pembelajaran yang berorientasi pada keaktifan siswa, diperlukan kemampuan guru dalam mendesain, mengimplementasikan dan mengevaluasi program pembelajaran yang dapat mendorong siswa mengembangkan kompetensi yang dipelajari dengan kemampuannya sendiri. Guru hendaknya mampu mengusahakan sumber belajar yang berguna serta dapat menunjang pencapaian tujuan dan proses belajar mengajar baik yang berupa narasumber, buku teks, majalah, ataupun surat kabar (Suwatra, 2015). Berbagai mata pelajaran diajarkan oleh guru di sekolah salah satunya Ilmu Pengetahuan Alam (IPA).

Ilmu Pengetahuan Alam (IPA) sebagai bidang studi yang mempelajari peristiwa-peristiwa di alam dapat menjadi salah satu sarana untuk memperoleh dan mengembangkan pengetahuan, sikap, dan keterampilan siswa baik secara konsep maupun aplikasinya dalam kehidupan sehari-hari. IPA merupakan mata pelajaran yang dimulai dari jenjang pendidikan dasar. Menurut Bundu (2006:11) secara garis besar, "IPA memiliki tiga komponen yakni sebagai produk, proses, dan sikap ilmiah". Sebagai produk, IPA merupakan sekumpulan pengetahuan dan sekumpulan konsep. Sebagai suatu proses, IPA adalah sejumlah keterampilan untuk mengkaji fenomena alam untuk memperoleh dan mengembangkan ilmu itu selanjutnya. Sedangkan yang dimaksud dengan sikap ilmiah adalah sikap dalam mencari dan mengembangkan pengetahuan baru seperti obyektif terhadap fakta, sikap ingin tahu, jujur, teliti, bertanggung jawab, dan terbuka. Menurut Sulthon(2016) Pembelajaran IPA tidak bisa dengan cara menghafal atau pasif mendengarkan guru menjelaskan konsep namun siswa sendiri yang harus melakukan pembelajaran melalui percobaan, pengamatan maupun bereksperimen secara aktif yang akhirnya akan terbentuk kreativitas dan kesadaran untuk menjaga dan memperbaiki gejala-gejala alam yang terjadi untuk selanjutnya membentuk sikap ilmiah yang pada gilirannya akan aktif untuk menjaga kestabilan alam ini secara baik dan lestari. 
Tujuan IPA secara umum adalah membantu siswa untuk mengembangkan pengetahuan dan pemahaman konsep-konsep IPA yang akan bermanfaat dan dapat diterapkan dalam kehidupan seharihari. Pembelajaran IPA diharapkan dapat menjadi wahana untuk membekali siswa dengan pengetahuan, sikap dan keterampilan untuk menyesuaikan diri dengan perubahan-perubahan di sekelilingnya. Melalui pendidikan IPA diharapkan dapat menumbuhkan kemampuan berpikir logis, rasional, analisis, dan kritis pada siswa dalam rangka mendukung perkembangan ilmu pengetahuan dan teknologi. Sehubungan dengan hal tersebut, dalam proses pembelajaran di sekolah khususnya di sekolah dasar, seorang guru diharapkan mampu menggunakan model-model pembelajaran yang inovatif, metode yang bervariasi dan penggunaan media yang tepat, agar siswa lebih aktif dan kreatif serta dapat saling bekerja sama, bertanggung jawab, saling membantu memecahkan masalah dalam mengikuti proses pembelajaran, dan apa yang menjadi tujuan pembelajaran dapat tercapai sesuai dengan yang diharapkan.

Pada kenyataannya yang terjadi di sekolah dasar menurut (Kusumayanti, Suarni, \& I Nym Murda, 2013), kecenderungan pembelajaran IPA sekarang ini peserta didik hanya mempelajari IPA sebagai produk, menghafal konsep, teori, dan hukum. Guru kurang kreatif untuk menciptakan kondisi yang mengarahkan siswa agar dapat membangun pengetahuannya sendiri. Kebanyakan dalam proses pembelajaran IPA guru masih menerapkan pembelajaran yang berpusat pada guru sehingga belum mampu membelajarkan siswa yang dapat berpengaruh terhadap hasil belajar IPA ke depannya. Menurut Hendrawan (2017), hasil belajar yang belum maksimal ini terjadi karena di dalam proses pembelajaran guru menggunakan metode ceramah yang dilandasi oleh interaksi satu arah dengan didominasi ceramah yang bermuara pada guru sebagai subjek dalam proses pembelajaran. Hal tersebut menyebabkan proses pembelajaran menjadi kurang bermakna dan siswa cenderung pasif dan kurang kreatif. Selain itu guru juga jarang memberikan belajar berkelompok sehingga siswa sangat jarang terlibat dalam diskusi interaksi antar siswa. Guru juga masih minim dalam penggunaan model pembelajaran yang inovatif dan menarik bagi siswa. Guru sangat jarang memberikan praktikum kepada siswa, guru hanya memberikan materinya saja sehingga siswa menjadi kurang aktif, cepat jenuh, bosan dan kurang percaya diri. Berbagai masalah dalam proses pembelajaran di kelas tentu akan berpengaruh pada hasil belajar siswa.

Berkaitan dengan pemaparan tersebut, permasalahan-permasalahan tersebut juga tampak terlihat di sekolah tempat dilaksanakannya penelitian. Hal ini diketahui dari hasil wawancara, observasi dan pencatatan dokumen yang dilaksanakan di Gugus VIII Kecamatan Sukasada Tahun Pelajaran 2017/2018. Gugus VIII Kecamatan Sukasada terdiri atas 5 (lima) SD dengan 1 (satu) SD untuk kelas V sudah menggunakan kurikulum 2013 dan 4 (empat) SD masih menggunakan kurikulum KTSP. Penelitian ini dilakukan pada SD yang menggunakan kurikulum KTSP. Hasil wawancara yang telah dilakukan dengan guru IPA kelas V di Gugus VIII Kecamatan Sukasada pada tanggal 8 dan 9 Januari 2018 didapatkan hasil wawancara dari 4 (empat) orang guru IPA di kelas V yaitu sebagai berikut. Pertama, 2 orang guru mengungkapkan bahwa, pembelajaran yang dilakukan masih bersifat konvensional dengan metode ceramah, tanya jawab, dan penugasan sedangkan 2 orang guru mengungkapkan bahwa, pembelajaran IPA kadang dilakukan dengan diskusi kelompok. Hal ini dilakukan agar siswa dapat bekerja sama dengan temannya di dalam kelompok. Kedua, 4 orang guru mengungkapkan bahwa, kebanyakan siswa merasa bosan dan jenuh dalam mengikuti proses pembelajaran IPA. Ketiga, 4 orang guru mengungkapkan bahwa, pembelajaran yang dilakukan jarang menggunakan media pembelajaran. Hal ini disebabkan karena kebanyakan dari guru mempunyai kesibukan yang padat sehingga itupun dapat dijadikan alasan yang membuat guru tidak membuat media pembelajaran. Keempat, hasil belajar yang diperoleh siswa masih rendah.

Hasil wawancara diperkuat dengan hasil observasi yang dilaksanakan pada tanggal 8 dan 9 Januari 2018 diperoleh hasil sebagai berikut. Pertama, dalam proses pembelajaran masih berpusat pada guru. Guru sebagai sumber informasi yang mendominasi pembelajaran dengan ceramah sedangkan siswa hanya mendengarkan, mencatat, dan menghafal materi yang diberikan. Kedua, siswa kurang aktif dalam proses pembelajaran. Ketiga, kurangnya motivasi belajar siswa di dalam proses pembelajaran. Keempat, kurangnya minat belajar siswa di dalam proses pembelajaran. Kelima, guru kurang menerapkan model pembelajaran yang inovatif dalam pembelajaran IPA. Selain kegiatan wawancara dan observasi, dilakukan pencatatan dokumen yang dilaksanakan pada tanggal 11 Januari 2018 diketahui bahwa, nilai kriteria ketuntasan minimal (KKM) yang ditetapkan untuk mata pelajaran IPA kelas V di Gugus VIII Kecamatan Sukasada berkisar dari 60-64, sedangkan hasil belajar IPA yang diperoleh siswa masih ada yang di bawah KKM. Hal tersebut dapat dilihat dari nilai UTS IPA kelas V di Gugus VIII Kecamatan Sukasada. Adapun nilai KKM dan rata-rata nilai UTS pada mata pelajaran IPA siswa kelas V seperti pada Tabel 1. 
Tabel. 1. Rata-rata Nilai UTS Mata Pelajaran IPA Siswa Kelas V

\begin{tabular}{|c|c|c|c|c|c|c|c|c|}
\hline \multirow{2}{*}{ No } & \multirow{2}{*}{ Nama Sekolah } & \multirow{2}{*}{$\begin{array}{c}\text { Jumlah } \\
\text { Siswa }\end{array}$} & \multirow{2}{*}{ KKM } & \multicolumn{2}{|c|}{ Tuntas } & \multicolumn{2}{|c|}{ Tidak Tuntas } & \multirow{2}{*}{$\begin{array}{c}\text { Rata- } \\
\text { rata }\end{array}$} \\
\hline & & & & Siswa & $\%$ & Siswa & $\%$ & \\
\hline 1 & SD Negeri 1 Kayuputih Melaka & 32 & 63 & 11 & 34,37 & 21 & 65,63 & 61,6 \\
\hline 2 & SD Negeri 2 Kayuputih Melaka & 16 & 64 & 4 & 25 & 12 & 75 & 62,7 \\
\hline 3 & SD Negeri 4 Kayuputih Melaka & 14 & 60 & 6 & 42,86 & 8 & 57,14 & 59,2 \\
\hline 4 & SD Negeri 5 Kayuputih Melaka & 13 & 61 & 6 & 46,15 & 7 & 53,85 & 59,6 \\
\hline & Jumlah & 75 & - & 27 & 36 & 48 & 64 & - \\
\hline
\end{tabular}

Berdasarkan Tabel 1 terlihat bahwa persentase siswa yang tuntas berkisar dari 25\% - 46,15\%. Hal tersebut menandakan masih banyak siswa yang belum memenuhi nilai kriteria ketuntasan minimal (KKM). Untuk menyikapi masalah-masalah tersebut, maka perlu diupayakan usaha peningkatan pemahaman dan penguasaan siswa terhadap materi pelajaran IPA yang nantinya sangat berpengaruh terhadap hasil belajar siswa. Permasalahan tersebut tentunya membutuhkan suatu solusi. Salah satu solusi yang dapat dilakukan adalah dengan menerapkan model pembelajaran kooperatif. Model pembelajaran kooperatif adalah suatu model pembelajaran yang menggunakan sistem pengelompokkan yang bekerja sama dengan sesama siswa untuk memecahkan masalah melalui diskusi dan kerja kelompok. Salah satu model pembelajaran yang dimaksud adalah model pembelajaran kooperatif tipe Two Stay Two Stray berbantuan Mind Mapping.

Pembelajaran kooperatif Two Stay Two Stray merupakan, "sistem pembelajaran kelompok dengan tujuan agar siswa dapat saling bekerja sama, bertanggung jawab, saling membantu memecahkan masalah, dan saling mendorong satu sama lain untuk berprestasi" (Huda, 2013:207). Struktur Two Stay Two Stray yaitu dalam satu kelompok terdiri empat siswa yang nantinya dua siswa bertugas sebagai pemberi informasi bagi tamunya dan dua siswa lagi bertamu ke kelompok yang lain secara terpisah. Model pembelajaran ini berbeda dengan model pembelajaran kooperatif lainnya, ciri model pembelajaran Two Stay Two Stray adalah dua orang tetap dikelompoknya dan dua orang lagi mencari informasi ke kelompok lainnya. Melalui model Two Stay Two Stray siswa berani mengemukakan pendapat karena adanya penyampaian informasi kepada kelompok lain dalam kegiatan pembelajaran. Model pembelajaran Two Stay Two Stray dapat menumbuhkan sikap kerja sama, motivasi dan keaktifan belajar siswa yang akan berdampak terhadap kompetensi pengetahuannya, karena siswa tidak hanya berbagi informasi kepada kelompoknya sendiri tetapi juga dengan kelompok lain.

Model pembelajaran akan lebih efektif jika didukung oleh media pembelajaran yang tepat. Peranan media sangatlah penting, yaitu sebagai alat bantu dan sarana yang dapat digunakan guru dalam menyampaikan materi. Salah satu media pembelajaran yang cocok digunakan dalam pembelajaran IPA dengan model kooperatif Two Stay Two Stray adalah Mind Mapping (peta pikiran). Silberman (dalam Shoimin, 2014:105) menyatakan, "Mind Mapping merupakan cara kreatif bagi tiap pembelajar untuk menghasilkan gagasan, mencatat apa yang dipelajari, atau merencanakan tugas baru”. Mind Mapping bertujuan membuat materi pelajaran terpola secara visual dan grafis yang dapat membantu merekam, memperkuat, dan mengingat kembali informasi yang telah dipelajari. Dengan adanya kombinasi warna, simbol, bentuk dan sebagainya memudahkan otak dalam menyerap informasi yang diterima sehingga siswa lebih lama dalam mengingat pembelajaran yang dijelaskan oleh gurunya. Utamanya dalam pembelajaran IPA, cakupan materi yang padat membuat siswa bosan dan malas untuk mempelajarinya.

Model pembelajaran kooperatif Two Stay Two Stray berbantuan Mind Mapping sangat tepat jika diterapkan dalam pembelajaran IPA di sekolah dasar, karena dengan menggunakan model pembelajaran kooperatif Two Stay Two Stray berbantuan Mind Mapping ini dapat membangun semangat dalam belajar dan siswa mampu memahami materi pelajarannya. Dalam menggunakan model pembelajaran kooperatif Two Stay Two Stray berbantuan Mind Mapping siswa dilatih untuk berpartisipasi aktif dalam pembelajaran secara merata serta menuntut siswa bekerja sama dengan kelompoknya. Maka dari itu, pembelajaran yang diajarkan kepada siswa tidak hanya berpusat pada guru melainkan pembelajaran ini berpusat pada siswa. Model pembelajaran kooperatif tipe Two Stay Two Stray berbantuan Mind Mapping dalam pembelajaran IPA memiliki dampak positif bagi siswa yang hasil belajarnya rendah karena model pembelajaran Two Stay Two Stray siswa dituntut untuk bekerja secara berkelompok sehingga siswa menjadi lebih aktif dan juga dapat mengkondisikan siswa dalam suatu lingkungan belajar yang nyaman karena di dalam kelompok siswa dapat saling tukar jawaban dan saling berbagi sehingga terjadi diskusi kelompok. Dengan menerapkan model pembelajaran kooperatif Two Stay Two Stray berbantuan Mind Mapping diharapkan siswa dapat menumbuhkan rasa kerjasama, bertanggung jawab dan lebih berperan aktif dalam proses pembelajaran sehingga berpengaruh terhadap hasil belajar siswa. 
Berdasarkan uraian yang telah dipaparkan maka dilakukan penelitian yang berjudul "Pengaruh Model Pembelajaran Kooperatif Two Stay Two Stray Berbantuan Mind Mapping Terhadap Hasil Belajar IPA Siswa Kelas V SD di Gugus VIII Kecamatan Sukasada Tahun Pelajaran 2017/2018". Tujuan penelitian ini adalah untuk mengetahui perbedaan yang signifikan hasil belajar IPA antara kelompok siswa yang dibelajarkan dengan model pembelajaran kooperatif Two Stay Two Stray berbantuan Mind Mapping dan kelompok siswa yang dibelajarkan dengan pembelajaran konvensional pada siswa kelas V SD di Gugus VIII Kecamatan Sukasada Tahun Pelajaran 2017/2018.

\section{Metode}

Penelitian ini dilaksanakan pada semester genap tahun pelajaran 2017/2018 pada siswa kelas V SD di Gugus VIII Kecamatan Sukasada. Penelitian ini merupakan penelitian kuasi eksperimen dengan menggunakan rancangan non-equivalent post-test only control group design. Populasi dari penelitian ini adalah seluruh siswa kelas V SD di Gugus VIII Kecamatan Sukasada Tahun Pelajaran 2017/2018 yang terdiri dari 4 SD yaitu SD Negeri 1 Kayuputih Melaka, SD Negeri 2 Kayuputih Melaka, SD Negeri 5 Kayuputih Melaka, dan SD Negeri 5 Kayuputih Melaka yang berjumlah 75 orang. Untuk mengetahui kesetaraan kemampuan siswa kelas $\mathrm{V}$ pada populasi, maka terlebih dahulu dilakukan uji kesetaraan dengan menggunakan analisis varians satu jalur (ANAVA A). Berdasarkan hasil analisis tersebut, ternyata tidak terdapat perbedaan hasil belajar pada ulangan tengah semester siswa. Berdasarkan hal tersebut, dapat dikatakan bahwa hasil belajar IPA pada siswa kelas V SD di Gugus VIII Kecamatan Sukasada adalah setara.

Teknik pengambilan sampel yang digunakan dalam penelitian ini adalah teknik random sampling. Sampel yang terpilih akan dirandom lagi untuk menentukan kelas eksperimen dan kelas kontrol. Kelas eksperimen pada penelitian ini adalah kelas V SD Negeri 4 Kayuputih Melaka yang berjumlah 14 orang, sedangkan kelas kontrol pada penelitian ini adalah kelas V SD Negeri 2 Kayuputih Melaka yang berjumlah 16 orang. Pada kelas eksperimen akan diberikan perlakuan model pembelajaran kooperatif Two Stay Two Stray berbantuan Mind Mapping, sedangkan pada kelas kontrol akan diberikan perlakuan pembelajaran konvensional.

Data yang dikumpulkan dalam penelitian ini adalah hasil belajar IPA siswa. Metode pengumpulan data dalam penelitian ini menggunakan metode tes. Tes hasil belajar IPA siswa ini berupa tes objektif atau pilihan ganda. Tes tersebut telah diuji coba di tempat penelitian sehingga teruji validitas, reliabilitas, daya beda, dan tingkat kesukaran tes. Hasil tes yang telah diuji coba selanjutnya diberikan kepada siswa kelas eksperimen dan kelas kontrol sebagai post-test. Analisis data yang digunakan dalam penelitian ini, yaitu analisis statistik deskriptif dengan menghitung nilai mean, median, modus, standar deviasi, dan varians dan statistik inferensial. Dalam penelitian ini, data disajikan dalam bentuk kurva polygon yang menunjukkan kecenderungan skor hasil belajar siswa. Teknik analisis data yang digunakan untuk menguji hipotesis penelitian adalah uji-t (polled varians). Sebelum melakukan uji hipotesis, dilakukan uji prasyarat yaitu uji normalitas dengan menggunakan rumus Chi-Kuadrat dan uji homogenitas menggunakan rumus uji F. Uji normalitas dilakukan untuk mengetahui apakah sampel berasal dari populasi yang berdistribusi normal. Sedangkan uji homogenitas dilakukan untuk mengetahui apakah sampel benar-benar homogen atau tidak.

\section{Hasil dan Pembahasan}

Pengukuran hasil belajar IPA dilakukan terhadap siswa pada masing-masing kelompok kelas yaitu kelas eksperimen dan kelas kontrol. Data hasil belajar IPA kelompok eksperimen diperoleh melalui post test terhadap 14 siswa. Hasil tes menunjukkan bahwa skor tertinggi adalah 29 dan skor terendah adalah 13. Dari skor yang diperoleh dapat dideskripsikan, yaitu mean sebesar 24,78, median sebesar 25,62, modus sebesar 26,26, varians sebesar 18,95, dan standar deviasi sebesar 4,35. Data hasil belajar IPA kelompok eksperimen, dapat disajikan ke dalam bentuk kurva poligon seperti pada Gambar 1. 


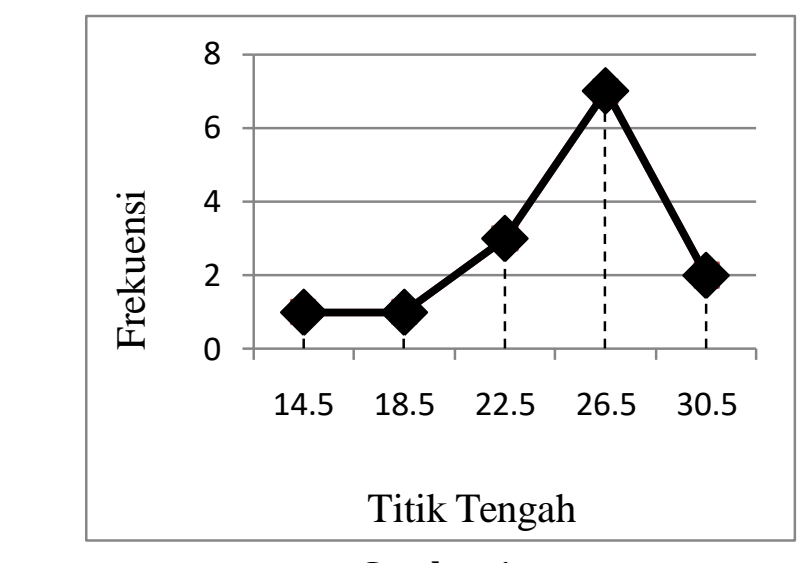

\section{Gambar 1. \\ Kurva Poligon Hasil Belajar IPA Siswa Kelas Eksperimen}

Berdasarkan kurva di atas, diketahui bahwa modus lebih besar dari median dan median lebih besar dari mean (Mo>Md>M). Dengan demikian kurva diatas adalah kurva juling negatif yang berarti bahwa sebagian besar skor cenderung tinggi. Data hasil belajar IPA kelompok kontrol diperoleh melalui post test terhadap 16 orang siswa. Hasil test menunjukkan bahwa skor tertinggi adalah 26 dan skor terendah 10. Dari skor yang diperoleh dapat dideskripsikan, yaitu mean sebesar 19,25, median sebesar 18,14, modus sebesar 16,34, varians sebesar 17,66, dan standar deviasi sebesar 4,20.

Data hasil belajar IPA kelompok kontrol, diketahui bahwa modus lebih besar dari median dan median lebih besar dari mean $(\mathrm{Mo}>\mathrm{Md}>\mathrm{M})$. Dengan demikian kurva diatas adalah kurva juling positif yang berarti bahwa sebagian besar skor cenderung rendah. Selanjutnya sebelum melakukan uji hipotesis, dilakukan uji normalitas sebaran data dan homogenitas kelompok varians. Uji normalitas data hasil belajar IPA siswa menggunakan rumus analisis Chi-Kuadrat $\left(X^{2}\right)$ pada taraf signifikan $5 \%$ dan derajat kebebasan $(\mathrm{dk})=\mathrm{n}-1$. Berdasarkan tabel nilai-nilai Chi-Kuadrat diperoleh $X^{2}$ tabel sebesar 5,591, dengan kriteria sebagai berikut: 1) Apabila harga $X^{2}$ hitung $<5,591$ maka $\mathrm{H}_{0}$ diterima atau $\mathrm{H}_{1}$ ditolak sehingga sebaran data hasil belajar IPA pada masing-masing kelompok dapat dikategorikan berdistribusi normal. 2) Apabila harga $X^{2}$ hitung $>5,591$ maka $\mathrm{H}_{0}$ ditolak atau $\mathrm{H}_{1}$ diterima sehingga sebaran data hasil belajar IPA pada masing-masing kelompok dapat dikategorikan tidak berdistribusi normal.

Berdasarkan analisis data uji normalitas yang dilakukan pada hasil belajar IPA di kelas eksperimen diperoleh $X^{2}$ hitung $=\sum \frac{\left(f_{0}-f_{e}\right)^{2}}{f_{\theta}}=3,25$. Harga tersebut kemudian dibandingkan dengan harga $X^{2}$ tabel dengan $\mathrm{dk}=2$ dan taraf signifikan 5\% sehingga diperoleh harga $X^{2}$ tabel $=5,591$, karena $X^{2}$ hitung $<X^{2}$ tabel $(3,25<$ 5,591) maka $\mathrm{H}_{0}$ diterima atau $\mathrm{H}_{\mathrm{a}}$ ditolak. Ini berarti sebaran data hasil belajar IPA kelompok eksperimen berdistribusi normal. Sedangkan analisis data uji normalitas yang dilakukan pada hasil belajar IPA di kelas kontrol diperoleh $X^{2}$ hitung $=\sum \frac{\left(f_{0}-f_{e}\right)^{2}}{f_{e}}=2,64$. Harga tersebut kemudian dibandingkan dengan harga $X^{2}$ tabel dengan $\mathrm{dk}=2$ dan taraf signifikan 5\% sehingga diperoleh harga $X^{2}$ tabel $=5,591$, karena $X^{2}{ }_{\text {hitung }}<X^{2}$ tabel $(2,64$ $<5,591$ ) maka $\mathrm{H}_{0}$ diterima atau $\mathrm{H}_{\mathrm{a}}$ ditolak. Ini berarti sebaran data hasil belajar IPA kelompok kontrol berdistribusi normal. Selanjutnya dilakukan pengujian homogenitas. Uji homogenitas untuk kedua kelompok digunakan uji F. Berdasarkan pengujian yang dilakukan, diketahui $\mathrm{F}_{\text {hitung hasil belajar kelas }}$ eksperimen dan kelas kontrol adalah 1,07 sedangkan $F_{\text {tabel }}$ pada dbembilang $=13$ dan $d_{b_{\text {penyebut }}}=15$ pada taraf signifikan $5 \%$ adalah 2,48. Hal ini berarti $\mathrm{F}_{\text {hitung }}<\mathrm{F}_{\text {tabel }}$ maka $\mathrm{H}_{0}$ diterima, ini berarti varian data hasil belajar IPA kelas eksperimen dan kelas kontrol adalah homogen.

Berdasarkan hasil analisis uji-t dengan rumus polled varians diperoleh thitung sebesar 3,53 sedangkan tabel dengan $\mathrm{db}=28$ pada taraf signifikan $5 \%$ adalah 2,04. Hasil perhitungan menunjukkan bahwa thitung $>t_{\text {tabel }}(3,53>2,04)$ sehingga $\mathrm{H}_{0}$ ditolak dan $\mathrm{H}_{1}$ diterima. Maka dapat disimpulkan bahwa terdapat perbedaan yang signifikan hasil belajar IPA antara kelompok siswa yang dibelajarkan dengan model pembelajaran kooperatif Two Stay Two Stray berbantuan Mind Mapping dan kelompok siswa yang dibelajarkan dengan pembelajaran konvensional pada siswa kelas V SD di Gugus VIII Kecamatan Sukasada Tahun Pelajaran 2017/2018.

Secara umum hasil penelitian ini menunjukkan bahwa terdapat perbedaan yang signifikan hasil belajar IPA antara kelompok siswa yang dibelajarkan dengan model pembelajaran kooperatif Two Stay Two Stray berbantuan Mind Mapping dan kelompok siswa yang dibelajarkan dengan pembelajaran konvensional. Hal ini dapat dilihat dari hasil belajar IPA yang dicapai oleh siswa. Secara deskriptif, hasil belajar IPA siswa pada kelompok eksperimen lebih tinggi dibandingkan dengan siswa pada kelompok 
kontrol. Rata-rata skor hasil belajar IPA yang diperoleh siswa pada kelompok eksperimen adalah 24,78 berada pada kategori sangat tinggi, sedangkan rata-rata skor hasil belajar IPA yang diperoleh siswa pada kelompok kontrol adalah 19,25 berada pada kategori tinggi. Perbedaan hasil belajar IPA antara kelompok siswa yang dibelajarkan dengan model pembelajaran kooperatif Two Stay Two Stray berbantuan Mind Mapping dan kelompok siswa yang dibelajarkan dengan pembelajaran konvensional disebabkan oleh beberapa hal.

Pertama, model pembelajaran kooperatif Two Stay Two Stray berbantuan Mind Mapping menjadikan siswa aktif dalam proses pembelajaran. Siswa aktif merupakan hal yang menandakan pembelajaran berjalan dengan baik. Pembelajaran yang melibatkan aktivitas siswa secara aktif akan mampu meningkatkan daya ingat siswa dalam memecahkan suatu permasalahan. Melalui pembelajaran aktif, siswa akan terlibat secara langsung dalam proses pembelajaran. Apabila siswa aktif dalam proses pembelajaran, siswa akan memeroleh pengalaman langsung yang menjadikan pembelajaran menjadi lebih bermakna dan siswa akan bersemangat dalam belajar. Hal ini sejalan dengan pendapat Hollingswort dan Lewis(dalam Riastini, 2016:48) yang menyatakan, "siswa belajar aktif ketika mereka terus menerus terlibat, baik secara mental ataupun fisik. Pembelajaran aktif itu penuh semangat, hidup, giat, berkesinambungan, kuat, dan efektif. Pembelajaran aktif melibatkan pembelajaran yang terjadi ketika siswa bersemangat, siap secara mental, dan bisa memahami apa yang dialami".

Kedua, model pembelajaran kooperatif Two Stay Two Stray berbantuan Mind Mapping memberikan kesempatan yang lebih banyak kepada siswa untuk berpendapat, bertanya, menjawab, dan saling membantu atau berinteraksi dengan temannya. Melalui kegiatan saling bertukar informasi kepada temannya menjadikan siswa mendapatkan pengetahuan lebih lengkap. Kegiatan belajar dalam kelompok yang lebih kecil ditambah lagi belajar dengan teman sejawat, membuat rasa canggung dan ketakutan siswa ketika belajar bersama guru tidak akan muncul. Siswa menjadi lebih berani menanyakan hal yang belum dimengerti dengan temannya dengan menggunakan bahasanya sendiri. Hal ini sejalan dengan pendapat Pratiwi (2016) yang menyatakan bahwa "melalui kegiatan berbagi informasi/pengetahuan dalam kerja kelompok dapat terciptanya hubungan timbal balik yang positif antar siswa yang satu dengan yang lain. Interaksi langsung dalam hubungan timbal balik yang bersifat positif dapat memengaruhi hasil pembelajaran".

Ketiga, model pembelajaran kooperatif Two Stay Two Stray berbantuan Mind Mapping dapat menjadikan suasana pembelajaran yang menyenangkan. Melalui pembelajaran yang menyenangkan siswa akan berkonsentrasi dan tertarik untuk menyimak materi dari guru. Pembelajaran yang menyenangkan mempunyai suasana yang membuat siswa gembira, tidak tertekan dalam belajar, semakin termotivasi, dan tidak membuat siswa takut dalam berinteraksi di dalam pembelajaran. Apabila pembelajaran dengan suasana yang menyenangkan sudah tercipta, maka perhatian siswa dalam pembelajaran akan lebih tinggi dan tujuan pembelajaran dapat dicapai dengan optimal. Hal tersebut sejalan dengan pendapat Saifudin, (2007) yang menyatakan bahwa pembelajaran yang menyenangkan mempunyai suasana yang mengasyikkan sehingga perhatian siswa terpusat secara penuh pada pembelajaran. Pembelajaran yang menyenangkan adalah kegiatan belajar yang menarik, meningkatkan motivasi siswa, mendapat pengalaman secara langsung, meningkatkan kemampuan berpikir kritis dan pemecahan masalah, serta tidak membuat siswa takut. Hal senada juga dikemukakan oleh Adiyatmaningsih (2014) yang menyatakan bahwa pembelajaran dengan menggunakan Mind Mapping menjadikan pembelajaran menjadi lebih menyenangkan yang nantinya membantu siswa dalam memahami dan mengingat konsep materi yang telah dijelaskan.

Dengan demikian, terbukti bahwa terdapat perbedaan yang signifikan hasil belajar IPA antara kelompok siswa yang dibelajarkan dengan model pembelajaran kooperatif Two Stay Two Stray berbantuan Mind Mapping dan kelompok siswa yang dibelajarkan dengan pembelajaran konvensional pada siswa kelas V SD di Gugus VIII Kecamatan Sukasada Tahun Pelajaran 2017/2018.

\section{Simpulan dan Saran}

Berdasarkan hasil pengujian hipotesis dan pembahasan, maka dapat disimpulkan bahwa terdapat perbedaan yang signifikan hasil belajar IPA antara kelompok siswa yang dibelajarkan dengan model pembelajaran kooperatif Two Stay Two Stray berbantuan Mind Mapping dan kelompok siswa yang dibelajarkan dengan pembelajaran konvensional pada siswa kelas V SD di Gugus VIII Kecamatan Sukasada Tahun Pelajaran 2017/2018. Perbedaan tersebut dapat dilihat dari rata-rata skor hasil belajar kelompok siswa yang dibelajarkan dengan model pembelajaran kooperatif Two Stay Two Stray berbantuan Mind Mapping sebesar 24,78 dan rata-rata skor hasil belajar kelompok siswa yang dibelajarkan dengan pembelajaran konvensional sebesar 19,25. 
Dengan demikian hasil belajar IPA kelompok siswa yang dibelajarkan dengan model pembelajaran kooperatif Two Stay Two Stray berbantuan Mind Mapping lebih baik dibandingkan dengan kelompok siswa yang dibelajarkan dengan pembelajaran konvensional pada siswa kelas V SD di Gugus VIII Kecamatan Sukasada Tahun Pelajaran 2017/2018 sehingga model pembelajaran Two Stay Two Stray berbantuan Mind Mapping berpengaruh terhadap hasil belajar IPA siswa. Ini berarti terdapat pengaruh yang signifikan model pembelajaran kooperatif Two Stay Two Stray berbantuan Mind Mapping terhadap hasil belajar IPA siswa kelas V SD di Gugus VIII Kecamatan Sukasada Tahun Pelajaran 2017/2018.

Adapun saran yang dapat disampaikan berdasarkan penelitian yang telah dilakukan adalah sebagai berikut. 1) Siswa hendaknya memanfaatkan pengalaman belajar yang lebih bermakna dan efektif dalam suasana yang menyenangkan, sehingga siswa menjadi lebih tertarik dalam proses pembelajaran khususnya pada mata pelajaran IPA dengan menggunakan model pembelajaran kooperatif Two Stay Two Stray berbantuan Mind Mapping sehingga hasil belajar yang dicapai lebih optimal. 2) Guru disarankan agar mencoba melakukan inovasi dalam pembelajaran khususnya pada mata pelajaran IPA seperti menggunakan model-model pembelajaran inovatif dan menggunakan media pembelajaran, salah satunya yaitu model pembelajaran kooperatif Two Stay Two Stray berbantuan Mind Mapping sehingga dapat berpengaruh positif terhadap hasil belajar IPA siswa. 3) Kepala sekolah hendaknya selalu mendukung penerapan model-model pembelajaran inovatif dalam proses pembelajaran di sekolah salah satunya model pembelajaran kooperatif Two Stay Two Stray berbantuan Mind Mapping sehingga nantinya dapat meningkatkan hasil belajar siswa. 4) Peneliti pemula hendaknya dapat menggunakan hasil penelitian ini sebagai bahan pertimbangan dan masukan sebagai acuan untuk mengembangkan penelitian berikutnya.

\section{Daftar Rujukan}

Adiyatmaningsih, N. P. H. (2014). Model Pembelajaran Berbasis Masalah Berbantuan Mind Mapping Berpengaruh Terhadap Hasil Belajar IPA Siswa Kelas V SD Gugus III Gianyar. Jurnal Mimbar PGSD Universitas Pendidikan Ganesha Jurusan PGSD, 2(1).

Bundu, P. (2006). Penilaian Keterampilan Proses dan Sikap Ilmiah (dalam Pembelajaran Sains Sekolah Dasar). Jakarta: Departemen Pendidikan Nasional.

Hendrawan, K. (2017). Pengaruh Model Pembelajaran Kooperatif Tipe TSTS Terhadap Hasil Belajar Siswa Kelas III SD. E-Jurnal PGSD Universitas Pendidikan Ganesha Mimbar PGSD, 5(2).

Herawati. (2015). Penerapan Model Pembelajaran Two Stay Two Stray untuk Meningkatkan Prestasi Belajar Siswa Pada Materi Keliling dan Luas Lingkaran di Kelas VI SD Negeri 53 Banda Aceh. Jurnal Peluang, 3(2), 95-105.

Huda, M. (2013). Model-Model Pengajaran dan Pembelajaran. Yogyakarta: Pustaka Pelajar.

Kusumayanti, D., Suarni, N. K., \& I Nym Murda. (2013). Pengaruh Strategi REACT Berbantuan Lingkungan Sebagai Sumber Belajar Terhadap Hasil Belajar IPA Kelas V di Gugus XIII Kecamatan Buleleng. Jurnal Universitas Pendidikan Ganesha, 1(1).

Pratiwi, N. K. C. (2016). Pengaruh Model Kooperatif Two Stay Two Stray Terhadap Hasil Belajar IPA. EJournal PGSD Pendidikan Ganesha Mimbar PGSD, 4(1).

Riastini, P. N. (2016). Pembelajaran IPA SD. Singaraja: Universitas Pendidikan Ganesha.

Sagala, S. (2012). Konsep dan Makna Pembelajaran. Bandung: Alfabeta.

Saifudin, M. (2007). Manajemen Berbasis Sekolah. Singaraja: Direktorat Jendral Pendidikan Tinggi.

Shoimin, A. (2014). 68 Model Pembelajaran Inovatif Dalam Kurikulum 2013. Yogyakarta: Ar-Ruzz Media.

Sulthon. (2016). Pembelajaran IPA yang Efektif dan Menyenangkan Bagi Siswa Madrasah Ibtidaiyah (MI). Elementary School of Education E-Journal, 4(1).

Susanto, A. (2013). Teori Belajar \& Pembelajaran di Sekolah Dasar. Jakarta: KENCANA.

Suwatra. (2015). Belajar dan Pembelajaran Sekolah Dasar. Singaraja: Undiksha. 